\title{
Pengaruh Model Pembelajaran Example Non Example Pada Materi Zat Aditif dan Zat Adiktif Terhadap Hasil Belajar IPA Siswa SMP Negeri 2 Pusomaen
}

\author{
Fitri Laode ${ }^{*}$, Zusje W. M. Warouw ${ }^{2}$ \\ 1,2 Jurusan Pendidikan IPA, FMIPA, Universitas Negeri Manado \\ *e-mail: fitriloade1999@gmail.com
}

\begin{abstract}
Abstrak. Minat dan motivasi belajar siswa yang masih kurang dalam mengikuti proses pembelajaran khususnya pada mata pelajaran IPA dan rendahnya hasil belajar serta siswa kurang berperan aktif masih menjadi masalah dalam pembelajaran. Penelitian ini bertujuan untuk mengetahui pengaruh model pembelajaran example non example pada materi zat aditif dan zat adiktif terhadap hasil belajar IPA siswa SMP Negeri 2 Pusomaen. Penelitian ini merupakan penelitian eksperimen semu, menggunakan rancangan penelitian pretest posttest control group design. Populasi dalam penelitian ini adalah seluruh kelas VIII di SMP Negeri 2 Pusomaen dan sampel penelitian ini terdiri atas 2 kelas, yaitu kelas VIII A sebagai kelas eksperimen yang berjumlah 19 siswa dan kelas VIII B sebagai kelas kontrol yang berjumlah 21 siswa. Pengambilan data dilakukan dengan memberikan pretest sebelum diberikan perlakuan dan posttest sesudah diberikan perlakuan. Data hasil penelitian yang diperoleh berupa selisih nilai rata-rata hasil pretest dan posttest pada kelas eksperimen adalah 57,10 sedangkan pada kelas kontrol adalah 51,14. Setelah diuji statistik melalui uji-t, diperoleh thitung $=4,180>$ $\mathrm{t}_{\text {tabel }}=1.685$. Dengan demikian dapat disimpulkan bahwa terdapat pengaruh model pembelajaran example non example pada materi zat aditif dan zat adiktif terhadap hasil belajar IPA siswa SMP Negeri 2 Pusomaen.
\end{abstract}

Kata kunci: example non example, hasil belajar

\begin{abstract}
Interest and motivation to learn students who are still lacking in following the learning process, especially in science subjects and low learning outcomes and students who do not play an active role are still a problem in learning. This study aims to determine the effect of the example non example learning model on additives and addictive substances on science learning outcomes for students of SMP Negeri 2 Pusomaen. This research is a quasi-experimental research, using a pretest posttest control group design. The population in this study were all class VIII at SMP Negeri 2 Pusomaen and the sample of this study consisted of 2 classes, namely class VIII $A$ as the experimental class which amounted to 19 students and class VIII $B$ as the control class which amounted to 21 students. Data collection was carried out by giving a pretest before being given treatment and a posttest after being given treatment. The research data obtained in the form of the difference in the average value of the pretest and posttest results in the experimental class is 57.10 while in the control class is 51.14. After statistical testing through $t$-test, obtained $t_{\text {count }}=4.180>t_{\text {table }}=1.685$. Thus, it can be concluded that there is an influence of the example non example learning model on the material of additives and addictive substances on the science learning outcomes of the students of SMP Negeri 2 Pusomaen.

Keywords: example non example, learning outcomes
\end{abstract}

Diterima 13 April 2021 | Disetujui 22 Juni 2021 | Diterbitkan 30 Juni 2021 


\section{PENDAHULUAN}

Pendidikan adalah usaha sadar dan terencana untuk mewujudkan suasana belajar dan proses pembelajaran agar peserta didik secara aktif mengembangkan potensi dirinya untuk memiliki kekuatan spiritual keagamaan, pengendalian diri, kepribadian, kecerdasan, akhlak mulia, serta keterampilan yang diperlukan dirinya, masyarakat, bangsa dan negara (Pemerintah Indonesia, 2003). Pada hakikatnya belajar adalah proses perubahan, baik yang menyangkut pengetahuan, keterampilan maupun sikap, bahkan meliputi segenap aspek organisme atau pribadi.

Belajar adalah suatu proses yang ditandai dengan adanya perubahan pada diri seseorang. Perubahan sebagai hasil proses belajar dapat ditunjukkan dalam berbagai bentuk seperti berubah pengetahuannya, pemahamannya, sikap dan tingkah lakunya, keterampilannya, kecakapannya dan lain-lain aspek yang ada pada individu (Sudjana, 2009).

Berdasarkan observasi yang di lakukan di SMP Negeri 2 Pusomaen ditemukan kurangnya minat dan motivasi belajar siswa dalam mengikuti proses belajar mengajar, khususnya pada mata pelajaran IPA di kelas VIII SMP Negeri 2 Pusomaen, serta rendahnya hasil belajar dan siswa tidak berperan aktif. Proses pembelajaran yang membuat minat atau keinginan belajar masih kurang karena siswa hanya mendengar apa yang disampaikan oleh guru sehingga hasil belajar siswa tidak mencapai Kriteria Ketuntasan Minimum (KKM) yaitu 70. Siswa sering bercerita dengan teman bahkan bosan berada di dalam kelas sehingga banyak yang minta izin keluar kelas dalam kegiatan pembelajaran berlangsung, karena guru masih menggunakan model konvensional.

Media berperan sebagai perangsang belajar dan dapat menumbuhkan motivasi belajar sehingga siswa tidak menjadi bosan dalam meraih tujuan belajar (Wijaya dalam Yensy, 2012). Salah satu model pembelajaran yang dipandang dapat mengatasi permasalahan tersebut di atas adalah model example non example.

Example non example adalah model pembelajaran yang membelajarkan siswa terhadap permasalahan yang di sekitarnya melalui analisis contoh berupa gambar, foto dan kasus yang bermuatan masalah. Murid diarahkan untuk mengidentifikasi masalah mencari alternatif pemecahan dan menetukan cara pemecahan yang efektif serta melakukan tidak lanjut (Komalasari dalam Shoimin, 2014). Example non example juga diartikan sebagai strategi belajar mengajar yang menggunakan gambar sebagai penyampaian materi pelajaran (Huda, 2013).

Keuntungan model examples non examples antara lain: (1) pembelajaran lebih menarik, sebab gambar dapat meningkatkan perhatian anak untuk mengikuti proses belajar mengajar, (2) siswa lebih cepat menangkap materi ajar karena guru menunjukkan gambargambar dari materi yang ada, (3) dapat meningkatkan daya nalar atau pikir siswa sebab ia disuruh guru untuk menganalisis gambar yang ada, (4) dapat meningkatkan kerja sama antara siswa sebab siswa diberikan kesempatan untuk berdiskusi dalam menganalisis gambar yang ada, (5) pembelajaran lebih berkesan sebab siswa dapat secara langsung mengamati gambar yang telah dipersiapkan oleh guru (Habibah, 2016).

Oleh karena itu, salah satu hal yang memiliki peranan penting untuk dapat meningkatkan hasil belajar siswa adalah dengan menggunakan model pembelajaran di sekolah yang merupakan tempat berjalannya proses pembelajaran. Salah satu model pembelajaran yang dapat digunakan adalah model example non example.

Model pembelajaran example non example adalah model pembelajaran yang menggunakan contoh-contoh. Contohcontoh dapat diperoleh dari gambar yang relevan dengan kompetensi dasar. Model pembelajaran example non example dapat menggantikan model pembelajaran konvensional (ceramah) untuk meningkatkan keaktifan siswa dalam proses pembelajaran, meningkatkan 
pemahaman siswa melalui analisis sebuah konsep, dan menjadikan pembelajaran lebih efektif dan bermakna. Hal tersebut diharapkan dapat meningkatkan hasil belajar siswa pada pembelajaran IPA (Hamdani, 2011).

Penelitian ini bertujuan untuk mengetahui pengaruh model pembelajaran example non example pada materi zat aditif dan zat adiktif terhadap hasil belajar IPA siswa SMP Negeri 2 Pusomaen.

\section{METODE PENELITIAN}

Metode penelitian yang digunakan adalah metode eksperimen semu. Tempat penelitian dilaksanakan di SMP Negeri 2 Pusoamen dan waktu penelitian dilaksanakan pada bulan oktobernovember tahun 2020.

Populasi dalam penelitian ini adalah siswa kelas VIII-A dan VIII-B di SMP Negeri 2 Pusomaen. Sampel dalam penelitian ini diambil menggunakan teknik purpose sampling untuk 2 kelas di kelas VIII-A yaitu berjumlah 19 siswa dijadikan kelas eksperimen dan kelas VIII-B berjumlah 21 siswa dijadikan kelas kontrol.

Desain yang digunakan dalam penelitian ini adalah quasi experimental design. Desain ini mempunyai kelompok kontrol, tetapi tidak berfungsi sepenuhnya untuk mengontrol variabelvariabel luar yang mempengaruhi pelaksanaan eksperimen (Sugiyono, 2014). Penelitian ini menggunakan nonequivalent control group design. Desain penelitian dapat dilihat pada Tabel 1.

\begin{tabular}{|c|c|c|}
\hline $\begin{array}{l}\mathrm{O}_{1} \\
\mathrm{O}_{3}\end{array}$ & $\begin{array}{l}\mathrm{X}_{1} \\
\mathrm{X}_{2}\end{array}$ & $\mathrm{O}_{2}$ \\
\hline
\end{tabular}

(Sugiyono, 2014)

Berdasarkan Tabel 1, $\mathrm{X}_{1}$ adalah pelaksanaan proses pembelajaran mengunakan model pembelajaran example non example, $\mathrm{X}_{2}$ adalah pelaksanaan proses pembelajaran mengunakan metode ceramah (konvensional), $\mathrm{O}_{1}$ dan $\mathrm{O}_{3}$ adalah tes awal, dan $\mathrm{O}_{2}$ dan $\mathrm{O}_{4}$ adalh tes akhir.
Penelitian ini terdiri dari dua variabel. Variabel bebas yaitu model pembelajaran example non example sebagai perbandingan dengan metode ceramah atau konvensional untuk menigkatkan hasil belajar siswa. Variabel terikat yaitu hasil belajar materi zat aditif dan zat adiktif sebagai variabel terikat dapat didefinisikan sebagai hasil yang telah dicapai oleh siswa setelah proses belajar.

Teknik pengumpulan data dilakukan dengan menggunakan tes dalam bentuk pretest (tes awal) dan posttest (tes akhir). Instrumen yang digunakan dalam penelitian ini berupa tes tertulis dalam bentuk pilihan ganda dan uraian.

Hipotesis dalam penelitian ini yaitu: $\mathrm{H}_{0}: \mu_{1} \leq \mu_{2}$ : rata-rata hasil belajar IPA siswa yang diajarkan menggunakan model pembelajaran example non example lebih rendah atau sama dengan hasil belajar IPA siswa yang diajarkan secara konvensional.

$\mathrm{H}_{\mathrm{a}}: \mu_{1}>\mu_{2}$ : rata-rata hasil belajar IPA siswa yang diajarkan menggunakan model pembelajaran example non example lebih tinggi dari hasil belajar IPA siswa yang diajarkan secara konvensional. Kriteria pengujian: tolak $\mathrm{H}_{0}$ jika thitung $>$ t tabel.

\section{HASIL DAN PEMBAHASAN}

Penelitian ini menggunakan dua kelas yaitu kelas VIII A yang berjumlah 19 siswa sebagai kelas eksperimen dan kelas VIII B dengan jumlah 21 siswa sebagai kelas kontrol. Kelas eksperimen merupakan kelas yang telah diberikan perlakuan dengan menggunakan model pembelajaran example non example sedangkan untuk kelas kontrol menggunakan model pembelajaran konvensional (ceramah), dengan materi zat aditif dan zat adiktif. Pembelajaran yang dilakukan juga merupakan tatap muka secara langsung, setiap pertemuan yang dilakukan didasari dari RPP yang telah disediakan terlebih dahulu, untuk kelas eksperimen selain menggunakan RPP juga menggunakan LKS dan media gambar yang telah disediakan oleh peneliti terlebih dahulu. 
Hasil yang diperoleh menunjukkan bahwa nilai rata-rata hasil posttest kelas eksperimen yang dicapai peserta didik adalah 80,2 lebih tinggi dari nilai ratarata posttest kelas kontrol 72,1. Data selengkapnya dapat dilihat pada Tabel 2 dan Tabel 3.

Tabel 2. Rekapitulasi skor hasil belajar kelas eksperimen

\begin{tabular}{llll}
\hline Statistik & Pretest & Posttest & Selisih \\
\hline $\begin{array}{l}\text { Skor } \\
\text { maksimum }\end{array}$ & 38 & 95 & 57 \\
$\begin{array}{l}\text { Skor } \\
\text { minimum }\end{array}$ & 15 & 70 & 55 \\
$\begin{array}{l}\text { Nilai rata- } \\
\text { rata }\end{array}$ & 23,15 & 80,26 & 57,10 \\
$\begin{array}{l}\text { Standar } \\
\text { deviasi }\end{array}$ & 7,01 & 8,07 & 1,05 \\
Varians & 49,25 & 65,20 & 15,95 \\
\hline
\end{tabular}

Tabel 3. Rekapitulasi skor hasil belajar kelas kontrol

\begin{tabular}{llll}
\hline Statistik & Pretest & Posttest & Selisih \\
\hline $\begin{array}{l}\text { Skor } \\
\text { maksimum }\end{array}$ & 30 & 85 & 55 \\
$\begin{array}{l}\text { Skor } \\
\text { minimum }\end{array}$ & 15 & 60 & 45 \\
$\begin{array}{l}\text { Nilai rata- } \\
\text { rata }\end{array}$ & 21 & 72,14 & 51,14 \\
$\begin{array}{l}\text { Standar } \\
\text { deviasi }\end{array}$ & 4,81 & 6,62 & 1,81 \\
Varians & 32,2 & 43,92 & 20,72 \\
\hline
\end{tabular}

Dari data pada Tabel 2 dan Tabel 3, dapat dilihat perbedaan rata-rata hasil pretest dan posttest dari kelas eksperimen dan kelas kontrol. Hal ini dikarenakan terdapat perbedaan perlakuan terhadap kedua kelas, dimana kelas eksperimen menggunakan model pembelajaran example non example sedangkan kelas kontrol hanya menggunakan metode konvensional (ceramah).

Berdasarkan data hasil penelitian yang diperoleh dari hasil belajar yang menggunakan model pembelajaran example non example pada kelas VIII-A sebagai kelas eksperimen dan kelas VIIIB sebagai kelas kontrol, menunjukkan bahwa kedua sampel yang di dapatkan berdistribusi normal dan perbandingan kemampuan pada kelas eksperimen dan kelas kontrol adalah homogen. Nilai thitung $=5,156>$ nilai $t_{\text {tabel }}=1,685$ pada taraf signifikan $a=0,05$. Berdasarkan kriteria pengujian hipotesis, apabila thitung lebih kecil atau sama dengan $t_{\text {tabel }}\left(t_{\text {hitung }} \leq t_{\text {tabel }}\right)$, maka $\mathrm{H}_{0}$ diterima dan $\mathrm{H}_{\mathrm{a}}$ ditolak. Karena data yang dianalisis diperoleh nilai thitung $>t_{\text {tabel }}$ maka, $\mathrm{H}_{0}$ ditolak dan $\mathrm{H}_{\mathrm{a}}$ diterima. Sehingga ditemukan bahwa terdapat pengaruh signifikan dari hasil belajar siswa yang menggunakan model pembelajaran example non example dan hasil belajar siswa yang menggunakan pembelajaran konvensional. Hasil belajar pada kelas eksperimen memiliki nilai rata-rata yang lebih tinggi yaitu 57,31 dibandingkan dengan nilai rata-rata hasil belajar pada kelas kontrol yaitu 49,85.

Perbedaan hasil belajar antara kelas yang menggunakan model pembelajaran example non example dan kelas yang menggunakan pembelajaran konvensional, menunjukkan bahwa model pembelajaran example non example sangat efektif dalam meningkatkan hasil belajar siswa, hal ini dapat dilihat dari hasil belajar yang menggunakan model pembelajaran example non example lebih tinggi dari hasil pembelajaran konvensional.

Hasil yang di dapat dari penelitian ini bersesuaian dengan penelitian sebelumnya yang dilakukan Wardika, Made Sulastri \& Dibia (2014) yang menunjukkan bahwa terdapat perbedaan yang signifikan antara kelompok siswa yang belajar menggunakan model pembelajaran example non example dengan kelompok siswa yang belajar menggunakan model pembelajaran konvensional. Sejalan dengan itu, hasil yang diperoleh dari penelitian Ariani, Mahadewi \& Rati (2017) menunjukkan bahwa pembelajaran dengan model pembelajaran example non example berpengaruh positif terhadap peningkatan hasil belajar IPA. Penelitian lainnya yang sejalan yaitu hasil penelitian dari Pratiwi, Agung \& Margunayasa (2019) yang mengemukakan bahwa terdapat pengaruh yang signifikan pada model pembelajaran example non example berbantuan alat peraga terhadap hasil belajar IPA. 


\section{KESIMPULAN}

Berdasarkan hasil penelitian dapat disimpulkan bahwa terdapat pengaruh model pembelajaran example non example pada materi zat aditif dan zat adiktif terhadap hasil belajar IPA siswa SMP Negeri 2 Pusomaen.

\section{DAFTAR PUSTAKA}

Ariani, K. D. D., Mahadewi, L. P. P., \& Rati, N. W. (2017). Pengaruh Model Pembelajaran Example Non Example Terhadap Hasil Belajar IPA Siswa Kelas V SD. e-Journal PGSD Universitas Pendidikan Ganesha, 5(2), 1-9

Habibah, S. (2016). Penggunaan Model Pembelajaran Examples Non Examples Terhadap Ketuntasan Hasil Belajar Siswa Pada Materi Tokoh-Tokoh Pergerakan Nasional Kelas V SDN 70 Banda Aceh. Jurnal Pesona Dasar, 3(4).

Hamdani. (2011). Strategi Belajar Mengajar. Bandung: Pustaka Setia.

Huda, M. (2013). Model-Model Pengajaran dan Pembelajaran. Yogyakarta: Pustaka Pelajar.

Pemerintah Indonesia. (2003). UndangUndang Republik Indonesia Nomor 20 Tahun 2003 Tentang Sistem Pendidikan Nasional. Lembaran RI Tahun 2003 No. 20. Jakarta: Sekretariat Negara.

Pratiwi, P., Agung, A. G., \& Margunayasa, I. G. (2019). Pengaruh Model Pembelajaran Examples Non Examples Berbantuan Alat Peraga terhadap Hasil Belajar IPA. Jurnal Pedagogi dan Pembelajaran, 2(2), 159-168.

Shoimin, A. (2014). 68 Model Pembelajaran Inovatif dalam Kurikulum 2013. Yogjakarta: Ar-Ruzz Media.

Sudjana, N. (2009). Penilaian Hasil Proses Belajar Mengajar. Bandung: PT Remaja Rosdakarya.

Sugiyono. (2014). Metode Penelitian Kuantitatif, Kualitatif dan R\&D. Bandung: Alfabeta.

Wardika, I. K., Made Sulastri, M. P., \& Dibia, I. K. (2014). Pengaruh Model Examples Non Examples Terhadap
Hasil Belajar IPA Siswa Kelas V SD di Gugus III Kecamatan Tampaksiring. MIMBAR PGSD Undiksha, 2(1).

Yensy, N. A. (2012). Penerapan Model Pembelajaran Kooperatif Tipe Examples Non Examples Dengan Menggunakan Alat Peraga Untuk Meningkatkan Hasil Belajar Siswa di Kelas VIII SMP N 1 Argamakmur. Exacta, 10(1), 24-35. 